\title{
Arquivos de Neuro-Psiquiatria: 75 years
}

\author{
Arquivos de Neuro-Psiquiatria: 75 anos
}

Hélio A. Ghizoni Teive ${ }^{1,2}$, Paulo Caramelli3,4

\begin{abstract}
This year marks the $75^{\text {th }}$ year of publication of Arquivos de Neuro-Psiquiatria (ANP), the official journal of the Brazilian Academy of Neurology and one of the most important neuroscience journals in Latin America. ANP was initially edited by Oswaldo Lange, its founder, and subsequently by Antonio Spina-França Netto and, in recent years, by José Antonio Livramento and Luís dos Ramos Machado.
\end{abstract}

Keywords: neurology; history; brazilian Academy of Neurology, Arquivos de Neuro-Psiquiatria.

\section{RESUMO}

Arquivos de Neuro-Psiquiatria (ANP), o periódico oficial da Academia Brasileira de Neurologia, completou 75 anos de atividades, reconhecido como um dos jornais de neurociências mais importante da América Latina. Nestes 75 anos de existência o ANP teve como editores os Professores Oswaldo Lange, o seu fundador, seguido por Antonio Spina-França Netto, e nos últimos anos, José Antonio Livramento e Luís dos Ramos Machado.

Palavras-chave: neurologia; história; Academia Brasileira de Neurologia; Arquivos de Neuro-Psiquiatria

Seventy-five years ago, in June 1943, the first edition of Arquivos de Neuro-Psiquiatria (ANP) was published under the editorship of the then assistant professor of Neurology at the University of São Paulo School of Medicine (FMUSP), Prof. Oswaldo Lange $\mathrm{e}^{1,2,3}$. The initiative had the full support of the two Neurology services in São Paulo at the time: the service at the Hospital das Clínicas of FMUSP, under Prof. Aderbal Tolosa, and the service at the São Paulo School of Medicine (EPMUNIFESP), coordinated by Prof. Paulino Watt Longo ${ }^{1,2,3,4}$. These full professors of Neurology wrote an editorial for the first edition of the ANP, in which they summarized the basic aims of the journal: "to satisfy the need for a journal to disseminate the fruits of scientific effort arising from the branching produced by the vitality of the tree planted by Enjolras Vampre'"s.

In 1970 the ANP became the official journal of the Brazilian Academy of Neurology (BAN) and has now been published unfailingly for 75 years $^{5}$. The aim of this article is to pay tribute to all the previous editors of ANP: the founder of the journal, Prof. Oswaldo Lange, Prof. Antonio Spina-França Netto and Profs. Luis dos Ramos Machado and José Antonio Livramento.

\section{OSWALDO LANGE: EDITOR FROM 1943 TO 1986}

Prof. Oswaldo Lange (Figure 1) was born in 1903 in the city of São Paulo and died in 1986 in the same city shortly before the age of $83^{1,2,3}$. After graduating in Medicine from the University of São Paulo in 1927, he worked at the FMUSP Neurology clinic with Professors Aderbal Tolosa and Paulino Watt Longo under the supervision of his professor and mentor Prof. Enjolras Vampré. When Vampré died in 1938, Aderbal Tolosa was appointed to the chair of Neurology and Lange became assistant professor, as well as chief resident ${ }^{1,2,3}$. He subsequently acquired an interest in cerebrospinal fluid (CSF), which lead to his thesis in 1938 on the characteristics of CSF in preclinical neurosyphilis, when he was appointed livre-docente" professor of Neurology at FMUSP, following a public examination ${ }^{1,2,3}$.

As chief resident, working full-time with an exclusive employment contract, he became extremely well known for his great scientific knowledge and the very rigorous, efficient manner in which he oversaw doctors under his guidance ${ }^{1,2,3}$. In 1943 he became the first editor of ANP, a position he held

\footnotetext{
${ }^{1}$ Universidade Federal do Paraná, Faculdade de Medicina, Departamento de Clínica Médica, Curitiba PR, Brasil;

2 Universidade Federal do Paraná, Hospital de Clínicas, Serviço de Neurologia, Curitiba PR, Brasil;

${ }^{3}$ Universidade Federal de Minas Gerais, Faculdade de Medicina, Departamento de Clínica Médica, Belo Horizonte MG, Brasil;

${ }^{4}$ Universidade Federal de Minas Gerais, Hospital das Clínicas, Serviço de Neurologia, Belo Horizonte MG, Brasil.

*An academic title conferred at Brazilian universities following a public examination or based on merit.

Correspondence: Hélio Afonso Ghizoni Teive; Rua General Carneiro 1103 / 102; 80060-150 Curitiba PR, Brasil; E-mail: hagteive@mps.com.br

Conflict of Interest: There is no conflict of interest to declare.
}

Received 28 November 2017; Accepted 07 December 2017. 
until his death, always performing his duties with great dedication and scientific rigor and displaying tremendous generosity toward his peers ${ }^{1,2,3,6}$.

At the end of 1943 Lange published an editorial in which he summed up what he hoped to achieve for ANP: "We cannot fail. We will overcome any obstacles to carry out this task. We will make ANP a journal that can match the best Brazilian journals and is comparable with similar journals in countries where the quality and quantity of journals suggest that Neuropsychiatry has reached a higher level. We shall repay the trust placed in us. And, above all, ANP will be a journal edited in São Paulo to serve Brazil" . To this day ANP upholds the mission and vision outlined by Prof. Oswaldo Lange.

\section{ANTONIO SPINA-FRANÇA NETTO: EDITOR FROM 1987 TO 2010}

Prof. Antonio Spina-França Netto (Figure 2) was born in 1927 in the city of Jaú, in the state of São Paulo, and died in 2010 in São Paulo, the capital, at the age of $82^{7}$. He graduated in Medicine from the University of São Paulo in 1951 and became the first neurology resident at the Hospital das Clínicas of FMUSP ${ }^{7}$. He acquired a solid knowledge of Neuroscience and was deeply influenced by Prof. Oswaldo Lange. Having also specialized in cerebrospinal fluid (CSF), he wrote his doctoral thesis on the electrophoresis of proteins in CSF. The thesis for his livre-docência" was in the same area (Betaglobulins in CSF). He was chief resident and, subsequently, full professor of Neurology at FMUSP ${ }^{7}$ and participated actively in setting up the school of Neurology in Botucatu, in the state of São Paulo.

Prof. Spina-França dedicated himself assiduously to the BAN and became a representative of the academy at the
World Federation of Neurology (WFN), of which he was later appointed vice-president ${ }^{7}$. Prof. Spina-França was also a cofounder of the Spina-França Neurodiagnostic Laboratory and the Center for Neurological Investigations (CNI) in the Department of Neurology at FMUSP ${ }^{7}$. He was editor of the ANP for over 20 years, a role he performed impeccably, making sweeping changes to the journal and modernizing the editorial process. One of his favorite mottoes, frequently mentioned by his colleagues, was "We have to transmit to the younger generation what was passed on to us by the older generation. That is why we are a school!"7.

\section{JOSÉ ANTONIO LIVRAMENTO AND LUÍS DOS RAMOS MACHADO: EDITORS FROM 2010 TO 2017}

José Antonio Livramento (Figure 3) was born in Recife, Pernambuco, in $1945^{\circ}$. He graduated in Medicine from the Federal University of Pernambuco (UFPE) in 1968 and was a Neurology resident at the Hospital das Clínicas, FMUSP, from 1969 to $1970^{8}$, since when he has followed an academic career. In 1978 he completed his masters in Neurology under the supervision of Prof. Spina-França with the dissertation "Immunoglobulins in Normal Cerebrospinal Fluid”. He defended his doctoral thesis in 1980 with the study "The Contribution of Immunofluorescent Reactions in Cerebrospinal Fluid to the Study of Neurocysticercosis", also under the supervision of Prof. Spina-França ${ }^{8}$. In 1986 he was awarded the livre-docência at FMUSP with his thesis "Cerebrospinal Fluid Syndrome in Neurocysticercosis". Prof. Livramento carried out numerous activities at FMUSP, the São Paulo Association of Medicine, the BAN, the WFN and the São Paulo Academy of Medicine ${ }^{8}$. From 2010 to 2017 he was editor of the ANP together with Prof. Machado, a duty he always performed with great elegance and dedication.

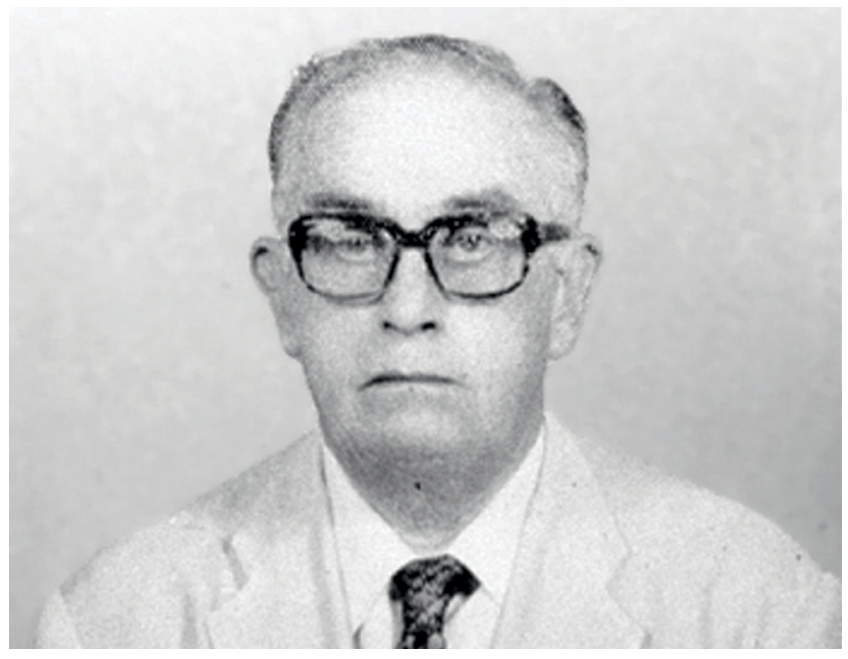

(Extracted from Google Images: Scielo.br, November 05 ${ }^{\text {th }}$, 2017)

Figure 1. Oswaldo Lange (Editor from 1943 to 1986).

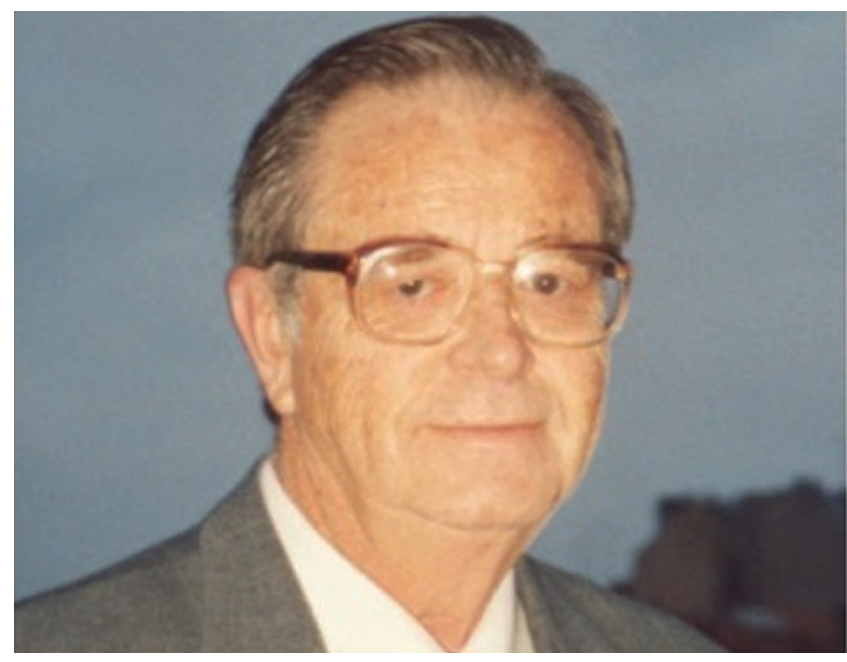

(Extracted from Google Images: Scielo.br, November 05th, 2017).

Figure 2. Antonio Spina-França Netto (Editor from 1987 to 2010). 


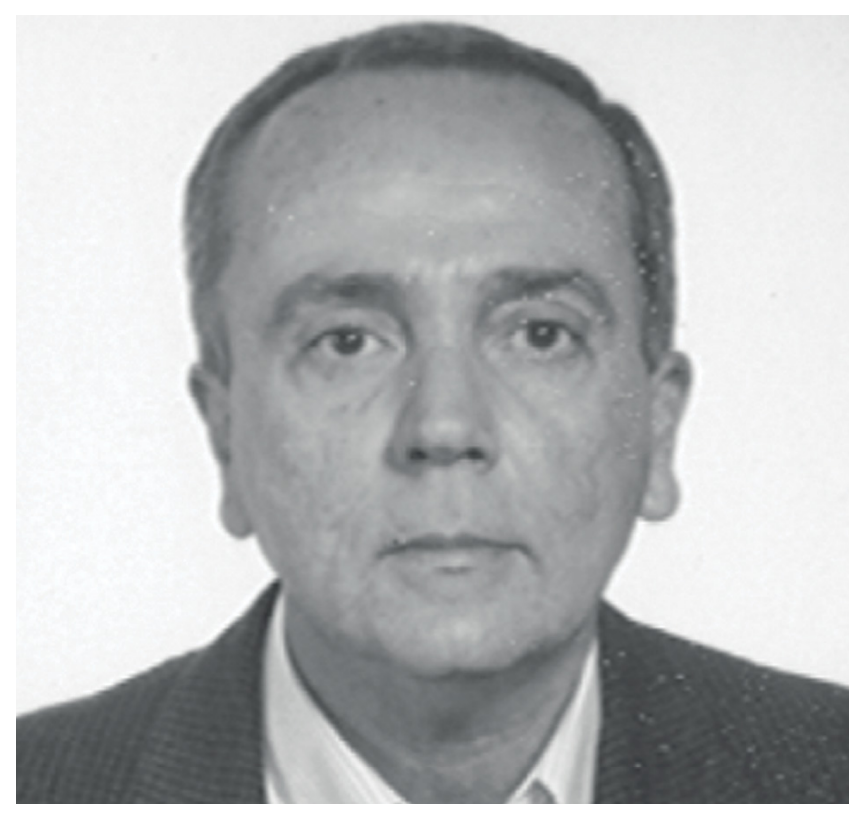

(Extracted from Reference 8).

Figure 3. José Antonio Livramento (Editor from 2010 to 2017).

Luís dos Ramos Machado (Figure 4) was born in the village of Rebordainhos, in Portugal, in $1945^{9}$. He graduated from FMUSP in 1974 and did his medical residency in Neurology in the Hospital das Clínicas at the same university9 . He completed his masters in Neurology in 1981 under the supervision of Prof. Horácio Martins Canelas with the dissertation "Lymphocyte Subpopulations in the Normal Cerebrospinal Fluid" and was awarded a $\mathrm{PhD}$ in 1987 with the thesis "Cerebrospinal Fluid and Neurocysticercosis: Evolutional Features of the Cellular Inflammatory Response", also under the supervision of Prof. Horácio Martins Canelas 9 . He has carried out numerous activities at FMUSP, including coordinating the outpatient unit for infectious diseases of the nervous system since 1996. He was an active member of the BAN and the São Paulo Association of Medicine and has been a member of the São Paulo Academy of Medicine since $1997^{9}$. From 2010 to 2017 he was a very dynamic joint editor of the ANP together with Prof. Livramento.

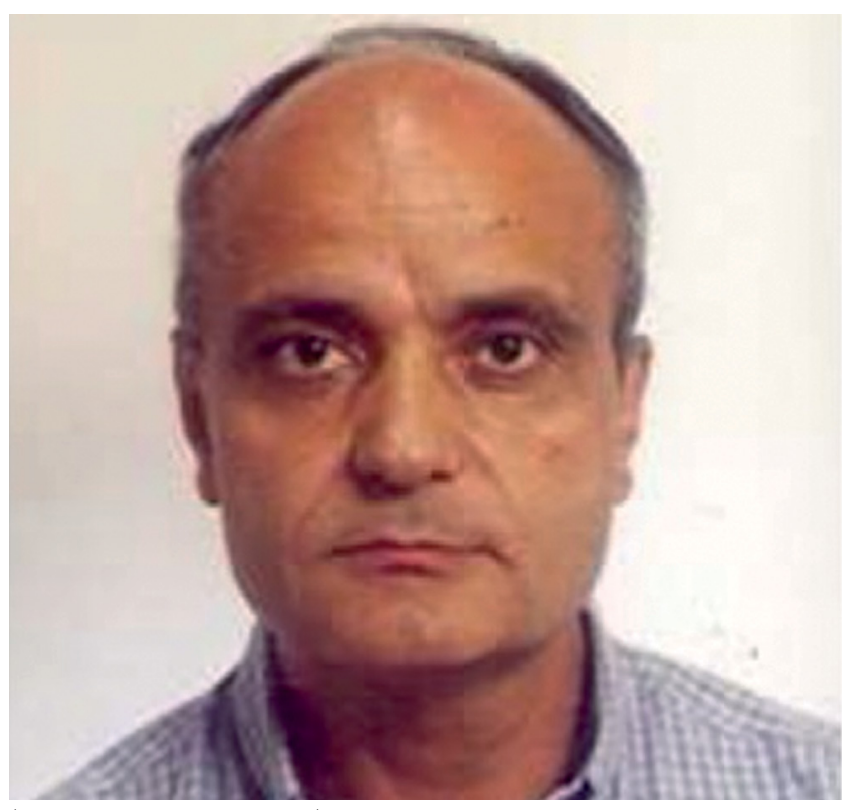

(Extracted from Reference 9).

Figure 4. Luís dos Ramos Machado (Editor from 2010 to 2017).

\section{CONCLUSION}

ANP, the official journal of the BAN, was first published in 1943 and is completing 75 years of uninterrupted activity in 2018. When the journal was launched, only few scientific journals in the area of Neurology existed worldwide and even fewer in Latin America. This scenario makes ANP a truly pioneer journal, which has significantly contributed to the advance of research in our country and continent. During its 75 years of existence, ANP has been edited by Prof. Oswaldo Lange, founder of the journal, Prof. Antonio SpinaFrança Netto, a disciple of Lange, and more recently, Prof. José Antonio Livramento and Prof. Luís dos Ramos Machado, disciples of Spina-França ${ }^{1,5,7,10}$. The dedicated work and the great contributions of these four editors at different times shaped ANP as a leading peer-reviewed journal in Clinical Neurology and Neurosciences in Latin America.

\section{References}

1. Spina-França A. Homenagem. Arq Neuropsiquiatr. 1986 dec;44(4):1-2. https://doi.org/10.1590/S0004-282X1986000400001

2. Spina-França A. O centenário do Dr. Oswaldo Lange. Arq Neuropsiquiatr. 2003 mar;61(1):1-6. https://doi.org/10.1590/S0004-282X2003000100001

3. Spina-França A. Oswaldo Lange e Arquivos de Neuro-Psiquitria. In: Reimão R. História da neurologia no Brasil. São Paulo: Lemos Editorial; 1999. p. 53-67.

4. Teive HAG. História da neurologia. In: Brasil Neto JP, Takayanagui OM. Tratado de neurologia da Academia Brasileira de Neurologia. São Paulo: Elsevier; 2013. p. 3-5.

5. Machado LR, Livramento JA. Arquivos de NeuroPsiquiatra in the Brazilian Academy of Neurology: natural evolution. Arq Neuropsiquiatr. 2015 dec;73(12):981-92. https://doi.org/10.1590/0004-282X2015018
6. Lange O. Sugestões para os que desejam publicar trabalhos. Arq Neuropsiquiatr. 1975;33(3):297-300.

7. Machado LR, Livramento JA. Prof. Spina-França. Arq Neuropsiquiatr. 2010;68(4):485-8. https://doi.org/10.1590/S0004-282X2010000400001

8. Academia de Medicina de São Paulo. José Antonio Livramento. [s.d.]. Available from: http://academiamedicinasaopaulo.org.br/ biografias/420/BIOGRAFIA-JOSE-ANTONIO-LIVRAMENTO.pdf

9. Academia de Medicina de São Paulo. Luís dos Ramos Machado. [s.d.]. Available fom: http://academiamedicinasaopaulo.org.br/ biografias/414/BIOGRAFIA-LUIS-DOS-RAMOS-MACHADO.pdf

10. Spina-França A. Os sessenta anos de Arquivos de NeuroPsiquiatria. Arq Neuropsiquiatr. 2002;60(4):1061-2. https://doi.org/10.1590/S0004-282X2002000600041 